\title{
The Morgan University STEM EXPO: A STEM Microscopy Workshop Offered at the Community Level
}

\author{
Frank Denaro $^{1 *}$, Letilia Givens ${ }^{1}$, Deven Hill-Bartlett ${ }^{1}$, Joshua Ross $^{1}$, Cornitra Sampson ${ }^{1}$, Simone E. \\ Sampson $^{1}$, Taiwozainat Smarton ${ }^{1}$ and Simon Nyaga ${ }^{1}$ \\ 1. Department of Biology, Morgan State University, Baltimore, MD, USA. \\ * Corresponding author: frank.denaro@morgan.edu
}

New developments in technology have led to the creation of very inexpensive microscopes [1]. This permits the students to have their own personal microscope. By introducing the "personnel monocular scope" to students in early science courses, a new dimension of personal inquiry begins to develop [2,3]. It is expected that microscopic enquiries will promote the student's curiosity. Moreover, with this microscope, students can report their data by cell phone videos or pictures, and communicate scientifically with each other. For example, we participated in the Morgan State University STEM EXPO and other community outreach activities with a Workshop on using the Foldscope (the monocular, origami microscope)[2]. We showed that the microscope has broad applications to STEM education and underscored its importance for research in many other areas of Science. In fact, the microscope is a useful tool across STEM disciplines. It is very important for Biology, but it is very useful in other STEM disciplines such as physics, chemistry, engineering etc. Therefore, microscopic studies are a useful entry point for STEM studies in general. The Baltimore city area is fortunate to have many science educational programs in which students can participate. This applies to K-12: elementary, middle, high school, or college levels. There are even openings for those who wish to volunteer. This allows students to find their areas of interest. Having their own personal microscope provides the opportunity to engage in discovery early following their own curiosity in their chosen area. By supplying the student with their own microscope they can make their own observations outside of classrooms.

It is to this end we arranged a Microscopic Workshop with a very inexpensive microscope (The Foldscope)[1]. This enabled us to give a Foldscope to each student who came to our Workshop. They assembled the Foldscopes themselves and used them to observe the specimens provided. After the workshop they took it home to make their own observations. Morgan Students at the Undergraduate and Graduate levels served as facilitators and helped the students with scope construction and specimen observation. We trained Morgan Undergraduate and Graduates in the construction and use of the Foldscope. These students then in turn mentored the Workshop attendees. This experience will enable them to serve effectively as facilitators within Morgan's Community outreach in STEM. The workshop included six steps and students were allowed to participate in some or all steps. Most participated in all of them. The description of the steps is given below. The Baltimore area is fortunate to have many science groups that permit student involvement. Some of these groups are known for promoting the concept of "Citizen Scientist". We sought out these different programs, listed, and summarized how the microscope may be a useful extension research tool in each program.

The MORGAN STATE UNIVERSITY STEM EXPO was organized by the Center for Excellence in Mathematics and Science Education (CEMSE) at Morgan State University. It hosted a number of schools in the Baltimore area. 
Steps in the Workshop presentation: we explained to the students, "Today you will learn by participating in 6 important steps: 1) Microscope assembly (Foldscope website with instructions for assembly: $\mathrm{https} / /$ www.foldscope.com/), 2) finding specimens to observe on the microscope, 3) making microscope slides to view, 4) taking cell phone pictures of your specimens, 5) communicate your information to friends, relatives, teachers, and workshop faculty and 6) talk about the student micrographs.

"These steps will give you experience with the monocular microscope. While this scope has only one lens, it is powerful with a magnification of $140 \mathrm{X}$ and 2 micron resolution. This allows you to examine the microscopic world and see single and multicellular organisms. Because the scope can visualize the cell (the fundamental unit of life) you can ask many questions".

Pre-Workshop preparation of training the Team: before the EXPO, Morgan Graduate students and undergraduates were trained and practiced the construction of the Foldscope. They also gained experience by using them to view a number of samples. They were then able to instruct students in the construction of the Foldscopes and in viewing slides at the workshop. The above six steps formed stations which had the needed supplies. The mentors were present to assist in the microscopic observations and image capture. The students were the encouraged to compare and discuss their observations. Over all reception of the Workshop approach was very enthusiastic [4].

\section{References:}

[1] JS Cybulski, J Clements and M Prakash, Foldscope: Origami-Based Paper Microscope. PLoS ONE 9(6) (2014), p. e98781. http://doi.org/10.1271/journal.pone.0098781

[2] F Denaro et al., Microsc. and Microanal. 24 (S1) (2018), p. 1374. doi: 10.1017/S1431927618007353

[3] F Denaro and S Nyaga, The 2018 PKAL Regional Network Conference (2018).

[4] The authors acknowledge funding from Grants: ASCEND grant 5UL1GM118973.

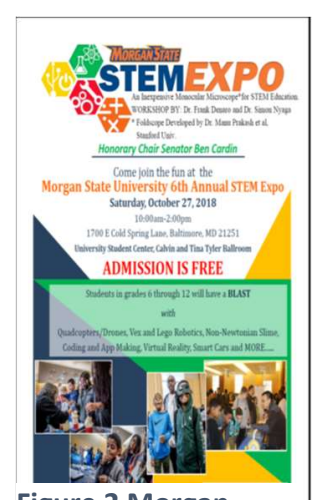

Figure 2 Morgan STEM EXPO. Morgan University hosts an annual STEM EXPO. Students from many Schools in the area attend.

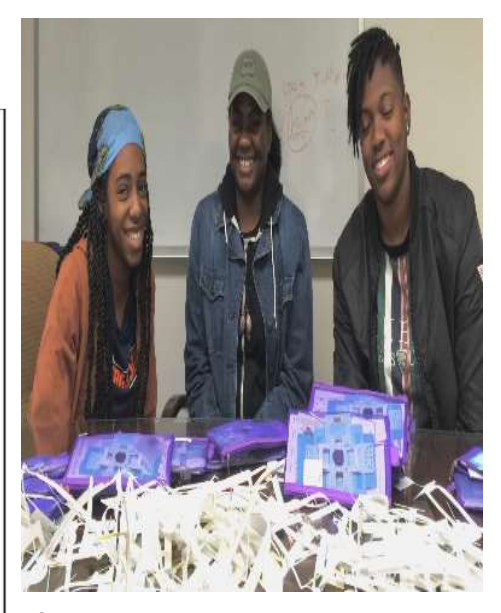

Figure 3 Morgan Mentor Team. The Morgan students put together many Foldscopes to give to attendees. The also helped with viewing and specimen descriptions.

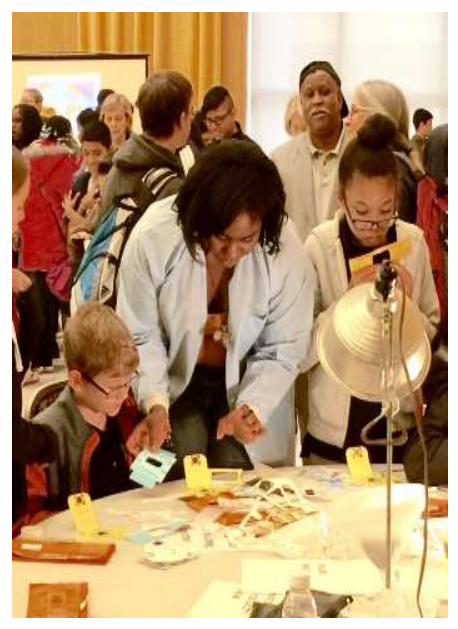

Figure 1 Morgan Mentor team helping students put the scopes together and make microscope slides.

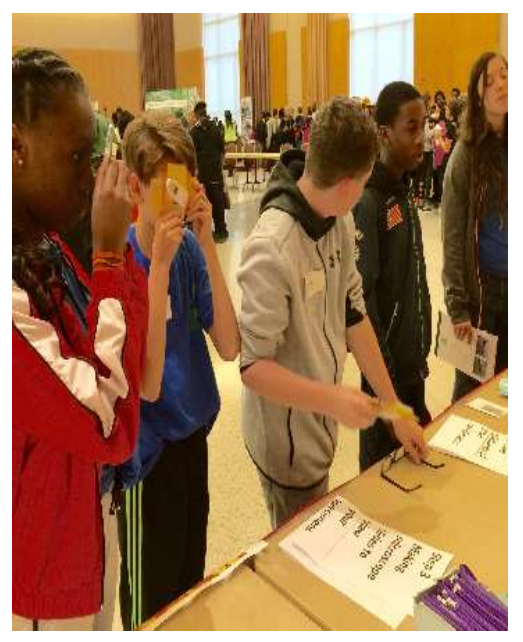

Figure 4 Students Observing the Specimens. Students were able to observe a both biological and chemical (crystals) specimens. 